\title{
Antioxidant activity and chemical composition of meat from broilers fed diets containing different essential oils
}

\author{
Izabela Lorena Azevedo(D), Wedson Carlos Lima Nogueira(D), Anna Christina de Almeida(D), Lis Lorena Melúcio Guedes(iD, \\ Claudia Regina Vieira (D), Sergio Henrique Sousa Santos (D), Carolina Magalhães Caires Carvalho(D,
} Francine Souza Alves da Fonseca (1D, Rogério Marcos de Souza(i) and Cintya Neves de Souza (D)

Federal University of Minas Gerais, Institute of Agrarian Sciences, Center for Research in Agrarian Sciences, Montes Claros, Minas Gerais, Brazil.

Corresponding author: Anna Christina de Almeida, e-mail: aca2006@ica.ufmg.br

Co-authors: ILA: azevedobella71@yahoo.com.br, WCLN: wedsonlima3@yahoo.com.br, LLMG: lislorenamelucio@gmail.com, CRV: crvieira70@gmail.com, SHSS: sergiosousas@hotmail.com, CMCC: carollcaires@yahoo.com.br, FSAF: francinefonseca@yahoo.com.br, RMS: rogeriosouza@ica.ufmg.br, CNS: cintyamicro@hotmail.com Received: 17-12-2020, Accepted: 28-04-2021, Published online: 25-06-2021

doi: www.doi.org/10.14202/vetworld.2021.1638-1643 How to cite this article: Azevedo IL, Nogueira WCL, Almeida AC, Guedes LLM, Vieira CR, Santos SH, Carvalho CMC, Fonseca FSA, Souza RM, Souza CN (2021) Antioxidant activity and chemical composition of meat from broilers fed diets containing different essential oils, Veterinary World, 14(6): 1638-1643.

\begin{abstract}
Background and Aim: Broiler meat is susceptible to lipid oxidation due to its high content of unsaturated fatty acids, especially when stored for a long time. Concerning with that problem, we can add natural compounds to the animal feed, as the plant essential oils, which have antioxidant, antimicrobial, and antifungal activities. The objective of this study was to evaluate the antioxidant activity, fatty acid profile, and chemical composition of the meat of broilers fed with diets containing different essential oil, including lemongrass (Cymbopogon flexuosus) and pedestrian tea (Lippia aff. rotundifolia).
\end{abstract}

\begin{abstract}
Materials and Methods: The experimental design used was a $4 \times 4$ factorial scheme (storage time $\times$ diets), and each treatment was repeated thrice. The treatments were applied as negative control (without antimicrobial); positive control (ration supplemented with $10 \mathrm{ppm}$ of enramycin and $42 \mathrm{ppm}$ of salinomycin), lemongrass (ration with $120 \mathrm{mg}$ of essential oil of lemongrass for each kilogram of live weight of the animals), and pedestrian tea (ration with $120 \mathrm{mg}$ of essential oil of pedestrian tea for each kilogram of live weight of the animals). Storage was performed after slaughter and evaluated monthly for 4 months.
\end{abstract}

Results: The inclusion of lemongrass oil and pedestrian tea in the broiler diet did not change the ether extract content of the meat sample obtained from thigh and drumstick. The storage time promotes an increase in the moisture loss of the meat from the $2^{\text {nd }}$ month in all treatments. There was an interaction between the additive and storage time for moisture loss. In the $2^{\text {nd }}$ month of storage, the meat from broilers fed the antibiotic-containing feed had a lower moisture loss than those from broilers in the other treatment groups. The fatty acid profile did not differ statistically between the different treatment groups. The inclusion of additives in the food dropped the lipid oxidation at the $2^{\text {nd }}$ month of storage. From the $3^{\text {rd }}$ month, however, only the essential oils showed antioxidant effect.

Conclusion: Antioxidant activity was positive for treatments that included essential oils. The lemongrass oil and pedestrian tea can be used as antioxidant additives in broiler diets to improve the oxidative stability of thigh-drumstick meat during storage. The results of the study suggest a good prospective for further research with profitability of usage essentials oils examined, for their economical application as feed components in broiler nutrition.

Keywords: broiler, Cymbopogon flexuosus, Lippia aff. rotundifolia, moisture, storage time.

\section{Introduction}

Broiler meat is largely used in most Brazilian meals and is one of the most consumed animal protein sources in the country. The per capita consumption of broiler meat in 2019 was approximately $42 \mathrm{~kg} / \mathrm{inhab}-$ itant/year. This high consumption value is associated with this meat being the cheapest protein and more accessible than fish, and also the poultry meat being considered healthy [1]. Broiler meat is susceptible to

Copyright: Azevedo, et al. Open Access. This article is distributed under the terms of the Creative Commons Attribution 4.0 International License (http://creativecommons.org/licenses/ by/4.0/), which permits unrestricted use, distribution, and reproduction in any medium, provided you give appropriate credit to the original author(s) and the source, provide a link to the Creative Commons license, and indicate if changes were made. The Creative Commons Public Domain Dedication waiver (http:// creativecommons.org/publicdomain/zero/1.0/) applies to the data made available in this article, unless otherwise stated. lipid oxidation due to its high content of unsaturated fatty acids. Lipid oxidation is accelerated during the handling, processing, storage, and cooking of meat products [2].

The synthetic antioxidants that are most widely used in the food industry as food preservatives are butylhydroxytoluene (BHT), butylhydroxyanisole, tertiary butylhydroxyquinone, and propyl gallate. At present, to meet the increasing consumer demands, there is a tendency to replace synthetic antioxidants with natural compounds that have the same function. Such natural compounds include plant essential oils that have antioxidant, antimicrobial, and antifungal activities [3].

The effect of adding essential oils to animal feed on meat quality is not well understood and raises safety concerns. Because this additive contains 
complex molecules, it is necessary to understand the synergism and antagonism of its constituents, the optimal concentration of each constituent, the possibility, and mechanism of their absorption by the gastrointestinal tract [4].

Therefore, this study aimed to evaluate the antioxidant activity, fatty acid profile, and chemical composition of thigh and drumstick meat from broiler chickens at 42 days of age fed with ration containing essential oils of lemongrass (Cymbopogon flexuosus $[\mathrm{CF}]$ ) and pedestrian tea (Lippia aff. rotundifolia).

\section{Material and Methods}

Ethical approval

The procedures were performed in accordance with ethical standards and approved by the Ethics Committee on Animal Usage, protocol no. 102/2013. The procedures adopted followed those described by Azevedo et al. [5].

\section{Study period and location}

The study was conducted from January to May 2015. The research was conducted in Montes Claros,

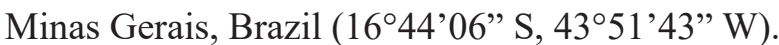

\section{Experimental design and bird husbandry}

A total of 150 male and female 1-day-old chicks of the Cobb 500 line were housed in cages $(60 \times 35 \times 100 \mathrm{~cm})$ with feeders and drinking fountains. The design used was a $4 \times 4$ factorial scheme (storage time $\times$ diets) in a completely randomized design, with three replicates per treatment. The storage time evaluated ranged from 1 to 4 months. The experimental treatments were as follows:

a) Negative control (NC): No antimicrobials and anticoccidials (NC)

b) Positive control (PC): Feed supplemented with $10 \mathrm{ppm}$ enramycin and $42 \mathrm{ppm}$ salinomycin (PC)

c) Lemongrass: Feed containing $120 \mathrm{mg}$ of $\mathrm{CF}$ essential oil for each kilogram of animal body weight $(\mathrm{CF})$

d) Pedestrian tea: Feed containing $120 \mathrm{mg}$ of Lippia rotundifolia (LR) essential oil for each kilogram of animal body weight (LR)

The dose used was defined from the antimicrobial activity presented by the essential oils of LR [6] and lemongrass [7] in preliminary in vitro tests.

\section{Experimental diets}

The nutrition plan was divided into three phases: Starter (1-21 days), grower (22-33 days), and finisher (34-42 days), as indicated by Rostagno et al. [8]. The diets were formulated to meet nutritional levels recommended by Rostagno et al. [8] and offered ad libitum throughout the experimental period in a mashed form (Table-1). The metabolizable energy and crude protein levels were, respectively, $3069.92 \mathrm{kcal} / \mathrm{kg}$ and $21.25 \%$ (starter diet); $3165.93 \mathrm{kcal} / \mathrm{kg}$ and $19.84 \%$ (grower diet); and $3215.51 \mathrm{kcal} / \mathrm{kg}$ and $18.43 \%$ (finisher diet).

The essential oil of lemongrass was purchased from Ferquima Indústria e Comércio LTDA (Vargem
Table-1: Composition of experimental diets.

\begin{tabular}{|c|c|c|c|}
\hline Ingredients & Initial & Growth & Final \\
\hline Corn $(\%)$ & 54.10 & 57.18 & 60.26 \\
\hline Soybean meal $46 \%(\%)$ & 37.49 & 33.75 & 30.20 \\
\hline Soy oil $(\%)$ & 4.494 & 5.163 & 5.652 \\
\hline Dicalcium phosphate (\%) & 1.571 & 1.338 & 1.200 \\
\hline Calcitic limestone (\%) & 0.910 & 0.865 & 0.778 \\
\hline Common salt (\%) & 0.483 & 0.458 & 0.446 \\
\hline DL-methionine (\%) & 0.147 & 0.142 & 0.132 \\
\hline L-lysine $(\%)$ & 0.064 & 0.075 & 0.102 \\
\hline Choline chloride (\%) & 0.055 & 0.050 & 0.037 \\
\hline Mineral Premix (\%) (1) & 0.050 & 0.050 & 0.050 \\
\hline Vitamin Premix (\%) (2) & 0.040 & 0.030 & 0.020 \\
\hline Inert (\%) & 0.600 & 0.900 & 1.200 \\
\hline Total (\%) & 100.0 & 100.0 & 100.0 \\
\hline \multicolumn{4}{|c|}{ Additives (mg. $\left.\mathbf{k g}^{-1}\right)$} \\
\hline Coccidiostat (\%) (3) & 0.050 & 0.050 & 0.050 \\
\hline Antimicrobial (\%) (4) & 0.012 & 0.012 & 0.012 \\
\hline $\begin{array}{l}\text { Cymbopogon flexuosus essential } \\
\text { oil (\%) (5) }\end{array}$ & 0.210 & 0.500 & 0.633 \\
\hline $\begin{array}{l}\text { Lippia rotundifolia essential oil } \\
(\%)(5)\end{array}$ & 0.210 & 0.500 & 0.633 \\
\hline \multicolumn{4}{|c|}{ Calculated content } \\
\hline Crude protein (\%) & 21.25 & 19.84 & 18.43 \\
\hline Metabolizable energy $\left(\mathrm{kcal} / \mathrm{kg}^{-1}\right)$ & 3069.92 & 3165.933 & 3215.51 \\
\hline Available phosphorus (\%) & 0.40 & 0.35 & 0.30 \\
\hline Calcium (\%) & 0.84 & 0.75 & 0.66 \\
\hline Sodium (\%) & 0.21 & 0.20 & 0.20 \\
\hline Lysine (\%) & 1.22 & 1.13 & 1.06 \\
\hline Methionine (\%) & 0.48 & 0.45 & 0.43 \\
\hline
\end{tabular}

(1) Each $\mathrm{kg}$ of trace mineral premix contains: $\mathrm{Cu}(\mathrm{min})$. 15 g. kg-1; Fe (min). $100 \mathrm{~g} \mathrm{~kg}^{-1}$; Mn (min). $140 \mathrm{~g} . \mathrm{kg}^{-1}$; Zn (min). $100 \mathrm{~g}^{\mathrm{kg}}{ }^{-1}$; I (min). $2.400 \mathrm{mg} . \mathrm{kg}^{-1}$; Se (min). $400 \mathrm{mg} \cdot \mathrm{kg}^{-1}$; inclusion of $500 \mathrm{~g} / \mathrm{t}$ of feed.

(2) Each $\mathrm{kg}$ of initial vitamin premix contains: vitamin A (min). 14.000.000.00 IU. $\mathrm{kg}^{-1}$; vitamin D3 (min).

4.400.000.00 IU. $\mathrm{kg}^{-1}$; vitamin E (min). 22.000.00 IU. $\mathrm{kg}^{-1}$, vitamin. $\mathrm{K} 3(\mathrm{~min}) .3 .200 .00 \mathrm{mg} \cdot \mathrm{kg}^{-1}$; vitamin $\mathrm{B} 1$ (min). $4.000 .00 \mathrm{mg} . ~ k g^{-1}$; vitamin B2 (min). $10.000 .00 \mathrm{mg}$. $\mathrm{kg}^{-1}$; vitamin B6 (min). $6.000 .00 \mathrm{mg} . \mathrm{kg}^{-1}$; vitamin B12 (min). 24.000 .00 mcg. $\mathrm{kg}^{-1}$; niacin (min). $70 \mathrm{~g} . \mathrm{kg}^{-1}$; pantothenic acid (min). $26 \mathrm{~g} . \mathrm{kg}^{-1}$; folic acid (min). $1.600 .00 \mathrm{~g} \mathrm{~kg}{ }^{-1}$; inclusion of $500 \mathrm{~g} / \mathrm{t}$ of feed. Growth Vitamin Premix containing per $\mathrm{kg}^{-1}$ of product: vitamin A (min). 12.000.000.00 IU. $\mathrm{kg}^{-1}$; vitamin D3 (min).

4.000.000.00 IU. $\mathrm{kg}^{-1}$; vitamin E (min). 20.000.00 IU. $\mathrm{kg}^{-1}$; vitamin $\mathrm{K} 3$ (min). 3.200 .00 mg. $\mathrm{kg}^{-1}$; vitamin $\mathrm{B} 1$ (min). $2.800 .00 \mathrm{mg} . \mathrm{kg}^{-1}$; vitamin B2 (min). $8.000 .00 \mathrm{mg} . \mathrm{kg}^{-1}$; vitamin B6 (min). 4.000 .00 mg. $\mathrm{kg}^{-1}$; vitamin B12 (min).

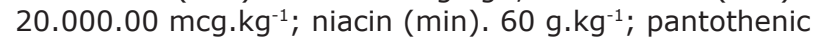

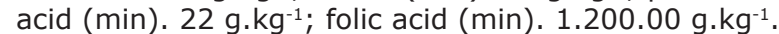

(3) Salinomycin coccidiostat for all phases at $500 \mathrm{~g} / \mathrm{t}$ of feed. (4) Antimicrobial enramycin for all phases at $125 \mathrm{~g} / \mathrm{t}$ of feed.

(5) Essential oil of Cymbopogon flexuosus/Lippia rotundifolia in the corresponding treatments.

Grande Paulista, SP, Brazil) and tea-pedestrian oil was purchased from producers at the Fundação do Vale do Jequitinhonha Cooperativa (Serro, district of São Gonçalo do Rio das Pedras, Minas Gerais, Brazil). Both oils were extracted by steam dragging and packed in $500 \mathrm{~mL}$ bottles. The oils were analyzed by a gas chromatograph coupled to a mass spectrometer (CG-EM). Subsequently, the oils were converted into microcapsules by Croma Microencapsulares (São Paulo, SP, Brazil) 
through coacervation with edible polymers. The microencapsulated essential oils were then mixed to the ration using a manual mixer for small quantities and stored in a freezer. After mixing, the rations were analyzed and the essential oils' volatile compounds were extracted in the static headspace and analyzed by CG-EM.

\section{Sample collection and analysis}

At 42 days of age, three birds were randomly selected from each experimental plot $( \pm 10 \%$ average weight), fasted for $8 \mathrm{~h}$, slaughtered by bleeding from the jugular vein, scalded, plucked, eviscerated, and cut. Each bird's thigh-drumstick was separated for further bromatological analysis, antioxidant activity determination, and fatty acid profiling. The cuts were weighed, cleaned, packed in well-labeled trays, and placed at $-18^{\circ} \mathrm{C}$ in the freezer until the time of analysis (storage conditions 1, 2, 3, and 4 months). Thigh-drumstick was chosen from among the cuts of greatest commercial value in Brazil and their physiological characteristics.

Bromatological analyses of protein and moisture contents were performed according to the method of the Adolfo Lutz Institute [9]. The lipid oxidation of the samples was determined through the Kreis reaction [9] which determines the quality of the meat fat. The methodology for preparing these derivatives was that described in Jham et al. [10], with some modifications. The first step was the hydrolysis of the hexane extract triacylglycerides $(10.00 \mathrm{mg})$ with addition of $\mathrm{KOH}$ solution in $\mathrm{MeOH}(1 \mathrm{~mL}, 0.5 \mathrm{~mol} / \mathrm{L})$ and heating at $100^{\circ} \mathrm{C}$ for $1 \mathrm{~h}$, under reflux. Posteriorly, $\mathrm{HCl}(400 \mathrm{~mL}, 36 \% \mathrm{v} / \mathrm{v})$ in methanol $(4: 1, \mathrm{v} / \mathrm{v})$ was added, maintaining the temperature at $100^{\circ} \mathrm{C}$, for $1 \mathrm{~h}$. After cooling, the extraction of methyl esters was performed with the addition of distilled $\mathrm{H}_{2} \mathrm{O}(2.0 \mathrm{~mL})$ and extracted with $\mathrm{CH}_{2} \mathrm{Cl}_{2}$, dichloromethane, $(2 \times 3.0 \mathrm{~mL})$. The organic phase was dried over anhydrous $\mathrm{MgSO}_{4}$, filtered, and concentrated on rotary evaporator. The residue obtained, after complete removal of the solvent was redissolved in $1.00 \mathrm{~mL}$ of $\mathrm{CH}_{2} \mathrm{Cl}_{2}$ and analyzed by GC-MS. The analysis of fatty acids was carried out according to the method of Azevedo et al. [5]

\section{Statistical analysis}

The results obtained from the factorial (diet $x$ storage time) experiments were subjected to analysis of variance using the $\mathrm{R}$ Statistical software $\mathrm{R}$ Core Team [11], and in the presence of significant effects of the interaction, the means were compared by the Tukey test $(\mathrm{p}<0.05)$. The statistical model used was as follows:

$$
Y i j k=\mu+\alpha i+\beta j+(\alpha \beta) i j+\varepsilon i j k,
$$

where, Yijk: A set of observations of the dependent variable corresponding to the storage time of the cuts $\mathrm{i}$, addition of essential oils $\mathrm{j}$, and repetition $\mathrm{k} ; \mu$ : A set of observations; $\alpha \mathrm{i}$ : Effect of the storage time of the cuts; $\beta \mathrm{j}$ : Effect of the addition of essential oils into the diet; $(\alpha \beta)$ ij: Effect of the interaction between storage time of the cuts $i$ and addition of essential oils in the order $\mathrm{j}$; and eijk: Experimental error from the observation of the effect of storage time of the cuts $i$, adding essential oils in the diet $\mathrm{j}$, and repetition $\mathrm{k}$.

\section{Results}

\section{Bromatological analysis}

The inclusion of lemongrass and pedestrian tea oils in broiler diet did not influence the ether extract content of the cuts compared with that of meat from other treatment groups (Table-2). With respect to storage time, ether extract content of the thigh-drumstick did not change significantly $(\mathrm{p}=0.150)$ during the 4 months.

The moisture was higher $(p<0.01)$ in the antibiotic treatment group with than in the NC group, pedestrian tea, and lemongrass groups (Table-2). The storage time contributed to a decrease $(\mathrm{p}<0.01)$ in the moisture content of the meat after the $2^{\text {nd }}$ month. There was an interaction between the additive and storage times with regard to moisture content $(p<0.01)$. Table- 3 shows that the inclusion of antimicrobials and anticoccidials to the rations improves the moisture of the thigh/drumstick cut during the $2^{\text {nd }}$ month of storage.

There was no significant difference in meat quality of the different groups in the $1^{\text {st }}, 3^{\text {rd }}$, and $4^{\text {th }}$ months of storage. However, in the $2^{\text {nd }}$ month, meat from the PC group had a higher moisture content compared with those from the other treatment groups. For all treatment groups, moisture content dropped from the $2^{\text {nd }}$ month of storage.

Fatty acid profile and lipid oxidation by the Kreis test

The composition of fatty acids did not differ significantly $(p>0.05)$ between meat from the different treatment groups (Table-4). Oleic and linoleic acid contents averaged $38.17 \%$ and $25.81 \%$, respectively, in meat from all groups.

Lemongrass oil, pedestrian tea, and antibiotics all exerted antioxidant action on the meat (Table-5).

Table-2: Analysis of ether extract (EE\%) and moisture (MO\%) of the broiler thigh/drumstick at 42 days of age.

\begin{tabular}{lcc}
\hline Additives & $\mathbf{E E}(\%)$ & MO $(\%)$ \\
\hline NC & $4.120 \pm 0.80$ & $73.625^{\mathrm{b}} \pm 0.72$ \\
PC & $4.579 \pm 0.68$ & $74.987^{\mathrm{a}} \pm 0.56$ \\
CF & $4.524 \pm 0.71$ & $73.770^{\mathrm{b}} \pm 0.63$ \\
LR & $4.738 \pm 0.88$ & $73.332^{\mathrm{b}} \pm 0.79$ \\
p-value & 0.2432 & $\mathrm{p}<0.01$ \\
Time (months) & & \\
1 & $4.575 \pm 0.76$ & $75.046^{\mathrm{a}} \pm 0.38$ \\
2 & $4.755 \pm 0.50$ & $73.768^{\mathrm{b}} \pm 0.33$ \\
3 & $4.624 \pm 0.65$ & $73.631^{\mathrm{b}} \pm 0.25$ \\
4 & $4.066 \pm 0.71$ & $73.270^{\mathrm{b}} \pm 0.30$ \\
p-value & 0.150 & $\mathrm{p}<0.01$ \\
Additives $\times$ Time & 0.3296 & $\mathrm{p}<0.01$ \\
CV & 16.78 & 1.72 \\
\hline
\end{tabular}

Mean \pm standard error standard. Similar superscripts in the same column do not differ significantly $(p<0.05)$.

$\mathrm{CV}$ : coefficient of variation

(NC) Feed negative control without additives; (PC) Feed positive control with antimicrobials and anticoccidials; (CF) Control feed + essential oil of Cymbopogon flexuosus; (LR) Control feed + essential oil of Lippia rotundifolia 
Table-3: Breakdown of the interaction between diets and storage time (month) for moisture (\%) in broilers at 42 days of age.

\begin{tabular}{lcccc}
\hline TRT & $\mathbf{1}$ (month) & $\mathbf{2}$ (month) & 3 (month) & $\mathbf{4}$ (month) \\
\hline NC & $75.060^{\mathrm{aA}} \pm 0.66$ & $73.550^{\mathrm{bB}} \pm 0.84$ & $74.093^{\mathrm{aB}} \pm 0.36$ & $73.800^{\mathrm{aB}} \pm 0.86$ \\
PC & $75.510^{\mathrm{aA}} \pm 0.80$ & $75.870^{\mathrm{aA}} \pm 0.41$ & $73.503^{\mathrm{aB}} \pm 0.42$ & $74.066^{\mathrm{aB}} \pm 0.79$ \\
CL & $74.986^{\mathrm{aA}} \pm 0.72$ & $73.876^{\mathrm{bB}} \pm 0.53$ & $73.553^{\mathrm{aB}} \pm 0.54$ & $73.666^{\mathrm{aB}} \pm 0.67$ \\
CP & $74.630^{\mathrm{aA}} \pm 0.56$ & $72.776^{\mathrm{bB}} \pm 0.65$ & $73.376^{\mathrm{aB}} \pm 0.48$ & $72.546^{\mathrm{aB}} \pm 0.53$ \\
\hline
\end{tabular}

Means \pm standard error followed by lowercase letters differ on the same column and the means \pm standard error followed by capital letters differ on the same line $(p<0.05)$. (NC) Feed negative control without additives; (PC) Feed positive control with antimicrobials and anticoccidials; (CF) Control feed + essential oil of Cymbopogon flexuosus; (LR) Control feed + essential oil of Lippia rotundifolia;

Table-4: Fatty acid profile of the thigh/drumstick of broilers at 42 days of age.

\begin{tabular}{lccccrr}
\hline Fatty acids & NC (\%) & PC (\%) & CF (\%) & LR (\%) & p-value & CV \\
\hline $\begin{array}{l}\text { Elaidic } \\
\text { (C18: } 1 \text { trans) }\end{array}$ & $0.80 \pm 0.16$ & $0.60 \pm 0.29$ & $0.83 \pm 0.23$ & $0.63 \pm 0.12$ & 0.340 & 24.83 \\
$\begin{array}{l}\text { Hexadecanoic } \\
\text { (C16:0) }\end{array}$ & $24.46 \pm 0.80$ & $23.20 \pm 0.75$ & $24.40 \pm 0.62$ & $25.80 \pm 0.51$ & 0.198 & 5.37 \\
$\begin{array}{l}\text { Linoleic } \\
\text { (C18: cis-9 cis-12) }\end{array}$ & $25.26 \pm 0.42$ & $25.66 \pm 0.54$ & $26.06 \pm 0.80$ & $26.26 \pm 0.46$ & 0.311 & 2.51 \\
$\begin{array}{l}\text { Oleic } \\
\text { (C18: } 1 \text { cis-9) }\end{array}$ & $38.66 \pm 0.45$ & $37.70 \pm 0.56$ & $38.23 \pm 0.71$ & $38.10 \pm 0.64$ & 0.780 & 2.99 \\
$\begin{array}{l}\text { Palmitoleic } \\
(16: 1 \mathrm{n}-7)\end{array}$ & $0.80 \pm 0.38$ & $1.30 \pm 0.52$ & $0.80 \pm 0.20$ & $1.32 \pm 0.41$ & 0.280 & 30.10 \\
\hline
\end{tabular}

(NC) Feed negative control without additives; (PC) Feed positive control with antimicrobials and anticoccidials;

(CF) Control feed + essential oil of Cymbopogon flexuosus; (LR) Control feed + essential oil of Lippia rotundifolia. (CV): coefficient of variation;

$a, b, c$ Mean \pm standard error bearing similar superscripts in the same row does not differ significantly $(p<0.05)$

Table-5: Lipid oxidation by the Kreis test of the thigh/ drumstick of broilers at 42 days of age.

\begin{tabular}{lllll}
\hline $\begin{array}{l}\text { Time } \\
\text { (months) }\end{array}$ & $\begin{array}{l}\text { NC } \\
\text { thigh/ } \\
\text { drumstick }\end{array}$ & $\begin{array}{l}\text { PC } \\
\text { thigh/ } \\
\text { drumstick }\end{array}$ & $\begin{array}{l}\text { CF } \\
\text { thigh/ } \\
\text { drumstick }\end{array}$ & $\begin{array}{l}\text { LR } \\
\text { thigh/ } \\
\text { drumstick }\end{array}$ \\
\hline 1 & $\mathrm{n}$ & $\mathrm{n}$ & $\mathrm{n}$ & $\mathrm{n}$ \\
2 & $\mathrm{p}$ & $\mathrm{n}$ & $\mathrm{n}$ & $\mathrm{n}$ \\
3 & $\mathrm{p}$ & $\mathrm{p}$ & $\mathrm{n}$ & $\mathrm{n}$ \\
4 & $\mathrm{p}$ & $\mathrm{p}$ & $\mathrm{n}$ & $\mathrm{n}$ \\
\hline
\end{tabular}

(NC) Feed negative control without additives; (PC) Feed positive control with antimicrobials and anticoccidials; (CF) Control feed + essential oil of Cymbopogon flexuosus; (LR) Control feed + essential oil of Lippia rotundifolia; ( $\mathrm{P}$ ) Positive; (N) Negative

Furthermore, lipid oxidation was absent in meats from the lemongrass and pedestrian tea groups throughout the storage period. The NC and PC groups showed lipid oxidation after the $2^{\text {nd }}$ month of storage.

\section{Discussion}

The use of essential oils in the feed did not affect the composition of ether extract of the meat. Figueiredo [4] evaluated the bromatological composition of the thigh-drumstick meat of broilers fed with different levels of essential oils of thyme and basil included in the feed. The ether extract was on average $4.51 \%$, similar to the results of this study.

The moisture content was the highest in the $1^{\text {st }}$ month of storage for all treatment groups. These values may be related to water loss to the environment. During the freezing, storage, and thawing processes, the meat loses water through evaporation, sublimation, and exudation, respectively. Evaporative losses depend on freezing conditions, as well as relative humidity and temperature, and the characteristics of the meat, such as the size and area-volume ratio of the pieces, fat cover, and the presence of skin or packaging [12]. From the $2^{\text {nd }}$ month of storage, there was a drop in moisture content in meat from all treatment groups. These results can be explained by the loss of water by evaporation during freezing [12].

The fatty acid composition of the meats from the different treatment groups did not differ statistically. These results are consistent with the findings of Figueiredo [4], who evaluated the fatty acid profile of meat from broiler chickens fed with different levels of essential oils of thyme and basil included in the feed. In that study, the oleic and linoleic acids were on average $37.50 \%$ and $20.97 \%$, respectively.

Our results show that the use of phytogenic additives in the feed may prevent lipid oxidation in the meat. Essential oils are rich in phenolic compounds (thymol, carvacrol, and eugenol), which can improve meat quality by reducing lipid oxidation and microbial growth $[5,13]$. According to Jayasena and Jo [14], these compounds prevent lipid oxidation by acting as free radical scavengers and hydrogen donors.

Luna et al. [15] used thymol and carvacrol, which are constituents of essential oils, in the feed of broilers. In that study, the NC group (without antioxidant) was compared with three others: PC (150 mg/ 
$\mathrm{kg}$ of BHT), $150 \mathrm{mg} / \mathrm{kg}$ thymol, and $150 \mathrm{mg} / \mathrm{kg}$ carvacrol. They found lower malonaldehyde levels in the thigh meat after 5 days of refrigeration in the thymol and carvacrol groups. This result indicated that thymol and carvacrol had a positive effect on meat preservation. Fratianni et al. [16] also evaluated the use of thyme essential oil in improving the shelf-life of fresh chicken breast meat stored at $4^{\circ} \mathrm{C}$. Inhibition of lipid peroxidation and deterioration of sarcoplasmic proteins were observed in the essential oil-treated meat, and the meat quality was maintained even after 2 weeks of storage.

Figueiredo [5] evaluated the antioxidant activity of essential oils in chicken breast, drumstick, and meatballs. The results showed that the addition of essential oils (Thymus vulgaris and Ocimum gratissimum) to the feed of broilers and processed meat (meatballs) effectively decreased lipid oxidation compared with that in the control group (without antioxidant addition). The antioxidant action observed following the inclusion of phytogenic compounds in the feed of broilers is likely exerted through absorption of the constituents into the body tissues, wherein they inhibit the reactions involved in lipid oxidation [17].

\section{Conclusion}

Essential oils of lemongrass and pedestrian tea can be used as antioxidant additives in broiler feed to improve the oxidative stability of the thigh-drumstick meat during storage. The results of the study suggest a good prospective for further research with profitability of usage essentials oils examined, for their economic application as feed components in broiler nutrition.

\section{Authors' Contributions}

ILA, WCLN, CRV, RMS, and ACA: Designed the study. WCLN, FSAF, ILA, LLMG, CNS, SMD, and ACA: Collected the data and did the laboratory work. WCLN, CRV, RMS, and ACA: Supervised the study. CMCC, WCLN, FSAF, CRV, and ACA: Analyzed the data and drafted the manuscript. CMCC, WCLN, SHSS, and ACA: Helped in critical review and data representation of the manuscript. All authors read and approved the final manuscript.

\section{Acknowledgments}

The authors express their gratitude to the Federal University of the Minas Gerais (PRPq/ UFMG) for providing the material and technical base and the CNPQ (National Council for Scientific and Technological Development), Fapemig (Minas Gerais State Research Support Foundation) (Grant no. APQ00219-13), and Capes (Coordination Improvement of Higher Education Personnel) Finance code 001 for receiving financial support for the study, and to the Laboratory of Instrumental Chemistry-ICA/UFMG, for support in the analysis.

\section{Competing Interests}

The authors declare that they have no competing interests.

\section{Publisher's Note}

Veterinary World remains neutral with regard to jurisdictional claims in published institutional affiliation.

\section{References}

1. Figueiredo, E.A. (2019) A Importância e Qualidade da Carne de Frango Brasileira. Available from: https://www. ainfo.cnptia.embrapa.br/digital/bitstream/item/204584/1/ final8479. pdf. Retrieved on 20-10-2020.

2. Soladoye, O., Juárez, M., Aalhus, J., Shand, P. and Estévez, M. (2015) Protein oxidation in processed meat: Mechanisms and potential implications on human health. Compr. Rev. Food sci. Food Saf., 14(2): 106-122.

3. Wei, A. and Shibamoto, T. (2010) Antioxidant/lipoxygenase inhibitory activities and chemical compositions of selected essential oils. J. Agric. Food Chem., 58(12): 7218-7225.

4. Figueiredo, A.N. (2017) Atividade Anti-Salmonella e Antioxidante de Uma Blenda de Óleos Essenciais Para uso em Dietas de Frangos de Corte. Tese de Doutorado, Universidade Estadual de Campina, UNICAMPI, Brazil.

5. Azevedo, I.L., Martins, E.R., Almeida, A.C., Nogueira, W.C.L., Filho, D.E.F., Santos, V.K.F. and Lara, L.J.C. (2017) Use of Lippia rotundifolia and Cymbopogon flexuosus essential oils, individually or in combination, in broiler diets. Rev. Bras. Zootec., 46(1): 13-19.

6. Souza, D.S., Almeida, A.C., Andrade, V.A., Marcelo, N.A., Azevedo, I.L., Martins, E.R. and Figueiredo, L.S. (2015) Atividade antimicrobiana do óleo essencial de Lippia origanoides e Lippia roduntifolia frente à enterobactérias isoladas de aves [Antimicrobial activity of Lippia origanoides and Lippia rotundifolia oils against enterobacteria isolated from poultry]. Arq. Bras. Med. Vet. Zootec., 67(3): 940-944.

7. Azevedo, I.L., de Almeida, A.C., Martins, E.R., Nogueira, W.C.L., de Faria Filho, D.E., de Oliveira, S.P., Prates, J.P.B. and Souza, C.N. (2016) Efeito in vitro do óleo essencial de "capim-limão" (Cymbopogon flexuosus Steud. Wats.) Contra bactérias entéricas de origem aviária. Acta Vet. Bras., 10(1): 5-31. Available from: https://www. periodicos.ufersa.edu.br/index.php/acta/article/view/5467. Retrieved on 14-03-2018.

8. Rostagno, H.S., Albino, L.F.T., Donzele, J.L., Gomes, P.C., Oliveira, R.F., Lopes, D.C., Ferreira, A.S., Barreto, S.L.T. and Euclides, R.F. (2017) Tabelas Brasileiras Para Aves e Suínos: Composição dos Alimentos e Requerimentos Nutricionais. $4^{\text {th }}$ ed. UFV, Viçosa.

9. Instituto Adolfo Lutz. (2008) Métodos Físico-Químicos Para Análise de Alimentos. $4^{\text {th }}$ ed. Instituto Adolfo Lutz, São Paulo.

10. Jham, G.N., Teles, F.F.F. and Campos, L.G. (1982) Use of aqueous $\mathrm{HCl} / \mathrm{MeOH}$ as esterification reagent for analysis of fatty acids derived from soybean lipids. J. Am. Oil Chem. Soc., 59: 132-133.

11. R Core Team. (2013) R: A Language and Environment for Statistical Computing. R Foundation for Statistical Computing, Vienna, Austria.

12. Hui, Y.H. (2006) Handbook of Food Science, Technology and Engineering. $3^{\text {th }}$ ed. Taylor e Francis, Flórida.

13. Krishnan, R.K., Babuskin, S., Babu, P.A.S., Sasikala, M., Sabina, K., Archana, G., Sivarajan, M. and Sukumar, M. (2014) Antimicrobial and antioxidant effects of spice extracts on the shelf life extension of raw chicken meat. Int. J. Food Microbiol., 171: 32-40.

14. Jayasena, D.D. and Jo, C. (2014) Potential application of essential oils as natural antioxidants in meat and meat 
products: A review. Food Rev. Int., 30(1): 71-90.

15. Luna, A., Lábaque, M.C., Zygadlo, J.A. and Marin, R.H. (2010) Effects of thymol and carvacrol feed supplementation on lipid oxidation in broiler meat. Poult. Sci., 89(2): 366-370.

16. Fratianni, F., de Martino, L., Melone, A., de Feo, V., Coppola, R. and Nazzaro, F. (2010) Preservation of chicken breast meat treated with thyme and balm essential oils. $J$. Food Sci., 75(8): 528-535.

17. Florou-Paneri, P., Palatos, G., Govaris, A., Botsoglou, D., Giannenas, I. and Ambrosiadis, I. (2005) Orégano herb versus orégano essential oil as feed supplements to increase the oxidative stability of turkey meat. Int. J. Poult. Sci., 4(11): 866-871.

$* * * * * * * *$ 